\title{
Shadow Archives
}





\title{
Shadow Archives
}

\section{The Lifecycles of}

\author{
African American
}

Literature

Jean-Christophe Cloutier 
Columbia University Press

Publishers Since I893

New York Chichester, West Sussex

cup.columbia.edu

Copyright $\left({ }_{20}\right.$ 20I9 Columbia University Press

All rights reserved

Library of Congress Cataloging-in-Publication Data

Names: Cloutier, Jean-Christophe, author.

Title: Shadow archives : the lifecycles of African American literature / Jean-Christophe Cloutier.

Description: New York : Columbia University Press, 2019. | Includes bibliographical references and index.

Identifiers: LCCN 2019006299 (print) | LCCN 2019011302 (ebook) | ISBN 9780231550246 (e-book) | ISBN 9780231193306 (cloth : alk. paper) |

ISBN 9780231193313 (pbk. : alk. paper)

Subjects: LCSH: American literature-African American authors-History and critcism. | American literature—2oth century-Information resources. |

American literature—2oth century—Research-Methodology. | African

Americans-Intellectual life—2oth century.

Classification: LCC PSi53.N $\mathrm{N}_{5}$ (ebook) | LCC PSi53. $\mathrm{N}_{5} \mathrm{C}_{53} 2019$ (print) |

DDC 810.9/896073-dc23

LC record available at https://1ccn.loc.gov/2019006299

Columbia University Press books are printed on permanent and durable acid-free paper. Printed in the United States of America

Cover image: Background photograph courtesy of the Samuel Roth estate.

Cover design: Lisa Hamm 
À Aimée, et au tout petit qui s'en vient<smiles>C=CC=C</smiles> 

I have not hesitated to use words which are old, and in some circles considered poetically overworked and dead, when I thought I could make them glow alive by new manipulation.

-CLAUDE MCKAY, HARLEM SHADOWS

In approaching our subject with the sensibilities of statisticians and dissectionists, we distance ourselves increasingly from the marvelous and spell-binding planet of imagination whose gravity drew us to our studies in the first place. This is not to say that we should cease to establish facts and to verify our information, but merely to suggest that unless those facts can be imbued with the flash of poetic insight then they remain dull gems; semi-precious stones scarcely worth the collecting.

-DANIEL DREIBERG, "BLOOD FROM THE SHOULDER OF PALLAS" 
